\title{
Art manager as a generator of the information world for art culture
}

\author{
Tatiana Suminova* \\ Moscow State Institute of Culture, 141406, Khimki, Russia
}

\begin{abstract}
In the context of post-industrial society, an informationalsemiotic approach becomes important for researchers, allowing to perceive, for example, art culture (art sphere)/art industry / art business as a unique world / Text / system, and the text of a work as a text itself, context and hypertext, forming info text. The appearance of certain documents / artifacts / information resources is associated with the activities of both the artist and representatives of other professions in the existing communicative space of art culture. In a market economy / creative economy / entertainment economy, a significant figure for "rotation" of communications in this area is the business assistant /organizer of the artist's business activity, that is, an art manager (agent, art dealer, entrepreneur, impresario, curator, promoter, producer, etc.). As a producer, using various technologies of art management (artistic, creative, organizational and managerial, including psychological, financial, economic, regulatory, marketing) in project activities, he creates demand and forms a proposal for the art market, generates, "Playing with beads" (G. Hesse) of ideas / meanings / contexts, the information world of art culture.
\end{abstract}

\section{Introduction}

With the entry of mankind into a new one - "post-industrial" (D. Bell, J. Galbraith), "superindustrial" (O. Toffler), "technotronic" (Z. Bzezhinsky), "information" (M. McLuhan, E. Masouda) era is the "revival" of scientific interest in the information-semiotic approach to culture, including the artistic.

Informational and semiotic ideas influence the development of philosophical and culturological thought, which makes it possible to study symbolic systems of culture, to conduct semiotic analyzes of cultural phenomena - literary works - as texts / meta-signs / concentrating and synergizing qualitatively new knowledge / specific meaning / meaning / information, and also to construct information models of processes in the field of culture.

This is carried out in the communicative space of artistic culture, which has several components. In a creative economy, one of the key figures in this is the figure of an intermediary - an art manager (agent, entrepreneur, impresario, promoter, producer, etc.), the specifics of which affects the creation of the information world of Art Text and its

\footnotetext{
* Corresponding author: tsuminova@yandex.ru
} 
morphology. All this testifies to the importance of art management and solving the problems of training industry managers who are able to make competent decisions, be effective and competitive for the benefit of the development of creativity, culture and the economy of the industry.

\section{Informational look at art culture}

A modern understanding of the surrounding world, reality as a text, the information world in which simulacra arise, exist and transform, forming super-reality, hyper-reality of literary texts, contribute to the emergence of opportunities for constructing a variety of intellectually innovative models, the creation of potential and non-potential artistic and informational virtual worlds .

It is the text that models, constructs the surrounding "void" (M. Foucault / J. Deleuze) and does not allow postmodern chaos to arise, affirming a fundamentally new model of thinking, essentially pluralistic and consisting in changing the view of the world / space / Universe / culture, etc. and leading to a change in the picture / image of the world of a particular artist and consumer of information.

Recipient in the act of reading and writing is called to recreate the structured, "scattered" text of the work. Hence, how many consumers of information, so many options for possible, virtual, informational "worlds" of the literary text, i.e. "endless dead end" of genesis.

There is also the problem of the creation, generation of cultural forms, literary texts, in which, thanks to hypertext non-linear connections, the fixed world acquires dynamics, instability, openness, "Brownian motion" and becomes a self-organizing informational chaos and at the same time the informational world.

The "micro-elements" signs present in the text of the work and its information world perform a deft game that occurs due to the simulacrum sign, "flickering" with the multiplicity of "traces" / bursts / energies / information objects, to which the consumer refers to in hypertext virtual information reality.

The recipient, falling into the rhizomatic chaos as the information world of the text of a work of art and having difficulty navigating in an interesting / mysterious labyrinth for him, feels lost in the wilds branched in all directions and continuing to branch hypertext transitions. Having adapted in this dense forest, the consumer understands that this is not chaos of decay, but chaos of generation, innovation of new images / worlds / ideas / knowledge / meanings / information, etc. It is language games with "micro-particles", "micro-elements" of the text as an integrated information world that allow him to build hyper-reality, virtual reality of the "read" text of the work.

Due to the fact that the texts of art works are multilingual, their symbiosis can be defined as the "super-language of simulacra" (Skoropanova, 2001), characterized by deconstruction, non-linearity, ambiguity, smooth character and involved in game relationships. It is this hybrid-quote super-language of simulacra that allows the decentration of a centered, i.e. subject to change the structure of the text / discourse / subject. Hence, the philosophy of the game becomes relevant as the basis for the "text philosophy."

Perceiving an art work as a text / information object, the question arises of a system of its three information levels: 1) the text of the work itself, directly written by the author; 2) the context of the work, including elements of the author's general cultural competence and the immediate conditions in which the work was created and which indirectly affected its content; 3) the hypertext of the work, including all the stated judgments about it, scientific and artistic criticism, etc. 
The defining figure, the subject of innovative activity and texts' generator of artistic culture / reality is, of course, the artist. His worldviews, the features of socialization, as well as the unique freedom of cultural innovation that he directly reflects the various cultural foundations of the "image of the world" in the text of the work included in the "treasury" of the indicated sphere of activity.

The quintessence of art culture is the field of art (artosphere from the English arto - art), which, along with the geosphere, biosphere, social and cognitive (cohort) aspects of human existence, is the most plastic element in the structure of the noosphere, which is manifested in the presence of it contains such a powerful system-forming principle as harmony (Suminova, 2005).

The options for the existence of art culture in a market economy are the art industry / show business and art business, related not only to spatial forms of art, but also to temporary and spatial-temporal / synthetic ones.

The results of the creative and intellectual activities of representatives of the artistic culture / art industry / art business form the world of Text / art text / text / art reality, which also is a holistic information world that creates, stores, translates and transforms symbolic information encoded in a particular language

\section{Art manager in the communicative information space of art culture}

The semiotic approach allows us to perceive artistic activity as a complex and ambiguous communication process that combines the three classic components - the artist / author, the text / work and the consumer / recipient.

In the context of a market economy, it is logical to represent and perceive the art culture as a communicative, including informational, world in the form of a polyhedron with vertex elements: text / art project / art product - author / artist / master - expert community of professionals - power - intermediaries - recipient / viewer / buyer of information.

The most important intermediary figure and, at the same time, the backbone element of the communicative information space of art culture / art industry / art business, without which functioning is difficult in the current economic conditions, is the art manager as a subject of cultural practice and an economic agent.

In the context of creative industries / creative entrepreneurship, an art manager is 1) a business assistant to an artist / artist working in the modern art market and its varieties and who needs to create texts of works / art products not only for self-realization, but also for realization / sales; 2) the organizer of business activities in the artistic culture / artosphere / art industry / art business, an entrepreneur who shapes both the taste and demand of information consumers and the space of the art market as a whole (Suminova, 2017).

Art managers using various technologies of art management (artistic, creative, organizational and managerial, including psychological (Suminova, 2014), financial and economic, regulatory, marketing), generate, rotating ideas / meanings / contexts, information world of art culture / artosphere / art industry / art business.

Art culture / art industry / art business is a type of information activity. According to the activity-information approach, each facet of the artist's life-giving activity generates an information-energy surge (information), subsequently clothed in a material form and called a text / work / document. That is why art culture itself is a generator of a huge number of various ideas / codes / symbols / signs / texts / documents / meanings, as well as cultural forms / artifacts (Flier, 2000, pp. 144 - 149.).

The information approach allows us to identify all ideas / meanings / documents / texts of works / cultural forms / artifacts with informational resources recorded on various media - traditional (paper) and non-traditional, including electronic (Suminova, 2006a). 
The morphology of the Text of artistic culture as an integral spectrum of information resources in accordance with the information and activity approach and the activity of the art manager consists of the following elements: 1) proper art, including preparatory information, or avantext, or genetic dossier, or metatext; or context; 2) biographical information; 3) art history information; 4) information and auxiliary materials (on traditional, non-traditional, including electronic, media) (Suminova, 1995); 5) organizational and management information (orders, instructions, etc.); 6) financial and economic information (estimates, business plans, etc.); 7) regulatory information (codes, laws, regulations, agreements); 8) marketing information (advertising and PR materials).

In the context of the information society development as a "systemic and long-term task" (Putin, 2007) of socio-cultural reality, as well as in order to increase the competitiveness of existing and trained specialists in the labor market, it is important to reveal the essence and identify the specifics of art management.

Art management is a socio-cultural concept of business reality, a component of the noosphere informational Universum, philosophy and management culture in the art culture (artosphere) / art industry / art business, industry management, science, applied academic discipline, subculture space, tool / mechanism creative industries, Russian and international economics and politics in the field of culture and art to meet the needs of recipients in the search for new meanings of being, in cultural values and in spectacles (exhibition and, plays, movies, etc.) (Suminova, 2017).

Art management and education in this field of activity are successfully developing in various foreign countries, for example, in the Netherlands in 2013 the European Research and Training Network on Art Management (ERTNAM) was created, the chairman which is Professor, Ph.D. Gip Hagoort; there is the interest in educational activity of the Nanyang Academy of Fine Arts (NAFA, Singapore), which implements the Arts Management Program.

In the context of the Russian state cultural policy implementation, the preparation of competitive and effective art managers as an intellectual resource / capital / asset is carried out in various universities in the field of culture and art. So, for example, at Management and Technologies of Social and Cultural Activities Department, State Cultural Policy Faculty Moscow State Institute of Culture T.N. Suminova is the head of the scientific school "Theory and Practice of Art Management", the author of numerous publications, the developer of the "Art Management" profile in the "Social and Cultural Activities" training area, according to which such students were graduated in 2019.

\section{Scientific elaboration of the problem}

The presented problems and the degree of its scientific development are described in detail by $T$. Suminova in the wide range of articles, lecture courses, manuals, textbooks, monographs (Suminova, 2005, 2016b), (Suminova, 2006a, 2006b), (Suminova, 2016a, 2017), (Suminova, 2014).

The relevance and significance of the art manager activities, as well as art management, or art management are evidenced by various publications on electronic (on-line) and traditional (paper) media. From periodicals, in this case - magazines (Humanities International Index), including academic ones, for example, in the UK - Journal of Arts Management \& Law; Journal of Arts Management, Law \& Society; The Journal of Arts Management, Law, and Society; in the USA - American Journal of Arts Management; in Canada - International Journal of Arts Management; South Australia - Asia Pacific Journal of Arts \& Cultural Management; in Russia - Art Manager.

A wide range of books (monographs, textbooks, manuals, reference books, etc.) by foreign authors, which disclose various problems of art management and the specifics of 
the art manager profession (Dreeszen \& Korza, 1994), (Brown \& Korza \& Dreeszen , 2009), (Radbourne \& Fraser, 1996), (Rosewall, 2013), (Rentschler, 1998; 2008), (Fitzgibbon \& Kelly, 1997), Dragicevic-Sesic \& Dragojevic, 2005), (Birnkraut \& Wolf, 2007), (Heinrichs \& Klein, 2004), (Shore, 1987), (Byrnes, 2003; 2014), (Berzins \& Nebel, 2006), (Taylor, 2018), (Pick, 1980), (Hsueh-li Hsia, 2012 ), (Chong, 2002; 2009), (Walter, 2015), (Brindle \& DeVereaux, 2011; 2015), (Horwitz, 1978), (Mandel, 2017), (Mandel. 2017), (Hagoort, 2000; 2005 ; 2009) and others.

\section{Goal of the research}

The goal of this research is to develop a theoretical, methodological and research approach to the "preparation" of the information world of art culture, generated through the effective and competitive activities of an art manager, which are "art dealers" / art communication intermediaries - agents, administrators, entrepreneurs, art dealers, directors, impresario, producers, promoters, etc. This approach allows revealing the essence, the specifics and genesis of art management and the activities of an art manager, which in the conditions of a creative economy / creative entrepreneurship and the implementation of state policy in the field of culture and art have a significant impact on the existence of art culture as a holistic information world / information system and to various processes occurring in such.

\section{Methodology and research methods}

The complex nature of the study determined the appeal to a whole range of scientific areas and approaches. These are structural and functional methodologies, semiotic, poststructuralist, postmodernist positions, etc.

The interdisciplinarity of the study determined the application of various approaches systemic, activity-based, informational, semiotic, morphological, cultural-historical, biographical, functional, philosophical, historical-genetic, comparative-cultural.

Moreover, the range of methods is significant - dialectical, comparative, longitudinal, systemic-structural, morphological analysis, semiotic analysis, comparative analysis.

\section{Conclusion}

Modern information society with "intelligent" computer technologies that allow infinitely changing spatio-temporal characteristics, and project activities require a new look at the artistic culture as one of the most important philosophical, cultural, semiotic, psychological, aesthetic, ethical, informational and other phenomena for the information world, the information system (Suminova, 2006b).

The development of semiotics had a significant impact on modern research conduction on artistic culture and its phenomena, which allowed us to create a holistic "picture" of such as a harmonious Text / information system / information world.

A key element of communication in the artistic culture (artosphere) / art industry / art business is the art manager, who is a producer in the field of culture and a producer of the culture sphere, since both generates and influences the generation of numerous information objects as such.

Today in Russia and in the world under the conditions of an impressions' economy, management in all spheres of life is significant, especially in the sphere of culture and art. Entrepreneurship in the industry also requires "systematic, organized, focused management" (Drucker, 2007, p. 223), in this case, art management. 
As prospects for further study of the problem under consideration, for example, the study of the genesis and history of the art manager profession in various components / types of art culture (artosphere) / art industry / art business, the identification of the specifics of the art management technologies used in the design process activities focused on the generation for the unique information world of Art Text.

\section{References}

1. I. Berzins, \& K. Nebel, Management of People, Brands, Media and the Arts (Rozes apgāds, Jāņa 2006).

2. G. Birnkraut, \& K. Wolf, Kulturmanagement Konkret: An Anatomy of Arts Management, (Institut fuer Kulturkonzepte, Hamburg, 2007).

3. M. Brindle, \& C. DeVereaux, (ed.), The Arts Management Handbook: New Directions for Students and Practitioners, (Routledge, 2011, 2015).

4. M. Brown, \& P. Korza, \& C. Dreeszen, Fundamentals of Arts Management, University of Massachusetts Amherst. USA: Amherst: Arts Extension Service, (2009).

5. W. J. Byrnes, Management and the Arts (Focal Press, Butterworth-Heinemann, Stoneham, 1993).

6. D. Chong, Arts Management (Routledge, London, 2002).

7. M. Dragicevic-Sesic, \& S. Dragojevic, Arts Management in turbulent times, (Boekmanstudies, Amsterdam, 2005).

8. C. Dreeszen, \& P. Korza, Fundamentals of Local Arts Managemen (Arts Extension Service, Amherst MA, 1994).

9. M. Fitzgibbon, \& A. Kelly, From Maestro to Manager: Critical Issues in Arts and Culture Management (Oak Tree Press, Dublin, 1997)

10. G. Hagoort, Art Management: Entrepreneurial style (Eburon, Delft, 2000).

11. G. Hagoort, Celebration of the end of Art Management. Kulturmanagement Konkret. An Anatomy of Arts Management, Interdisciplinary Positions and Perspectives. (Kultur Konzepte, Vienna, 2009).

12. W. Heinrichs, \& A. Klein, Arts Management from $A$ to $Z$ (Chinese Edition, Five Senses, 2004).

13. T. Horwitz, Arts Administration: How to Set Up and Run a Successful Nonprofit Arts Organization (Chicago Review Press, Chicago, 1978).

14. Hsueh-li H. J. Dr., Arts Management (Chinese Edition, 2012).

15. Humanities. Information on :https://www.ebscohost.com/titleLists/hgh-coverage.pdf

16. B. Mandel, Arts / Cultural Management in International Contexts (Georg Olms Verlag, 2017).

17. J. Pick, Arts Administration (Spon, London, 1980).

18. J. Radbourne, \& M. Fraser, Arts Management. A Practical Guide (Allen \& Unwin Pty LTD, St. Leonards, Australia, 1996).

19. R. Rentschler, Shaping Culture. Arts and Entertainment Management, University of New South Wales Press (UNSW Press) in cooperation with Deakin University Press, (1998).

20. R. Rentschler, Entrepreneurial Arts Leader: Cultural Policy, Change and Reinvention (University of Queensland Press, Australia, 2008) 
21. E. Rosewall, Arts Management: Uniting Arts and Audiences in the 21st Century, (Oxford University Press, Great Britain, 2013).

22. H. Shore, Arts Administration and Management. A Guide for Administrators and Their Staffs (Quorum Books, USA, 1987).

23. J. Taylor, Visual Arts Management, (Routledge, London, 2018).

24. C. Walter, Arts Management: An entrepreneurial approach (Routledge, 2015).

25. Peter F. Drucker, Business and Innovation, Trans. from English Moscow: LLC I.D. Williams, (2007).

26. V.V. Putin, Opening address at a meeting of the Security Council on the development of the information society in Russia, (2007). Information on http: //www.kremlin.ru/events/president/transcripts/24432

27. I.S. Skoropanova, Russian postmodern literature: a new philosophy, a new language (Nevsky Prostor, St. Petersburg, 2001).

28. T.N. Suminova, Nikita Mikhalkov: filmography and bibliogrraphy decrees (TRITE Studio - Russian Archive, Moscow, 1995).

29. T.N. Suminova, Noosphere: the search for harmony (Academic Project, Moscow, 2005).

30. T.N. Suminova, Information resources of art culture (artosphere) (Academic Project, Moscow, 2006a).

31. T.N. Suminova, Art culture as an information system (worldview and theoretical and methodological grounds) (Academic Project, Moscow, 2006b).

32. T.N. Suminova, Psychological technologies of art management: a training manual (MGUKI, Moscow, 2014).

33. T.N. Suminova, Art management: a textbook for students of higher educational institutions studying with specialty "Socio-cultural activity" (51.03.03 and 51.04.03) with major "Management of socio-cultural activity." (MGIK. Part 1., Moscow, 2016a).

34. T.N. Suminova, Artosphere: essence and specificity: a course of lectures on the discipline "Art Management" for students of higher educational institutions (MGIK, Moscow, 2016b).

35. T.N. Suminova, Art management: the implementation of state policy in the field of culture and art (Academic project, Moscow, 2017).

36. A.Y. Flier, Culturology for culturologists: a textbook for undergraduates and graduate students, doctoral students and applicants, as well as teachers of cultural studies (Academic Project, Moscow, 2000). 